УДК94(477.7):330, $526.36 \ll 1914-1917 »$

\title{
КООПЕРАТИВНИЙ РУХ НА ПІВДНІ УКРАЇНИ В УМОВАХ ПЕРШОЇ СВІТОВОЇ ВІЙНИ
}

\section{Пятницькова Ірина}

Стаття присвячена особливостям розвитку кооперативного руху на Півдні України в умовах Першої світової війни. Методологічну основу дослідження складає комплекс загальнонаукових та історичних методів пізнання: методи логічного аналізу, синтезу, порівняння, класифікації, проблемно-хронологічний, історико-типологічний, статистико-аналітичний. Було дотримано принципів історизму, наукової об'єктивності та системності. Комплексний аналіз наукової літератури та джерел із застосуванням означених методологічних підходів дає можливість зробити ряд висновків.

Розгортання Першої світової війни створило нові соціально-економічні умови розвитку кооперативного руху. Вони полягали у скороченні державного фінансування; мобілізацї частини членів та прачівників кооперативів; дефіциті товарів та підвищенні изін; проблематичності пошуку товаропостачальників; призупиненні темпів розвитку сільського господарства та зменшенні потреби в кооперативному кредитуванні.

У результаті адаптації кооперативного руху до воєнних умов спостерігалося збільшення кількості споживчих товариств, діяльність яких була спрямована на забезпечення населення якісними та прийнятними за иінами товарами. Інтенсивність розвитку кредитних та сільськогосподарських кооперативів у роки війни зменшилась. Товариства цих напрямів діяльності розширили обсяги посередницьких операцій з забезпечення армї сільськогосподарською продукиією. Особливу увагу кооперативні товариства приділяли благодійності, допомагали армії, родинам мобілізованих членів. Важливість дослідження полягає в актуалізаиії иієї проблеми на регіональному рівні; комплексному вивченні особливостей розвитку кооперативного руху Півдня України в умовах Першої світової війни. Дослідження иієї теми не є вичерпаним, воно потребує подальшого вивчення, зокрема уточнення статистичних показників, аналізу культурно-просвітницької діяльності.

Ключові слова: війна, кооперативний рух, соціально-економічні відносини, товариство.

Перша світова війна стала важливим рушієм не лише політичних, а й соціально-економічних змін. 3 iї розгортанням спостерігалося скорочення обсягів виробництва, призупинення темпів капіталізації сільського господарства, стрімкий ріст інфляції, а разом $з$ тим - і цін.

Одним із характерних явищ соціально-економічного розвитку українських земель на початку XX ст. було розгортання кооперативного руху. На Півдні України діяли споживчі, кредитні, сільськогосподарські товариства, різноманітні за напрямами діяльності артілі та кооперативні союзи. Регіон займав провідні позиції з розвитку кредитної кооперації. Розгортання кооперативного руху в регіоні сприяла більш широкому залученню населення до товарно-грошових відносин, запровадженню нових технологій у сільське господарство, що позитивно вплинуло на підвищення його продуктивності. 
В умовах Першої світової війни кооперативні товариства вимушені були адаптуватися до нових соціально-економічних викликів. У результаті цього процесу тенденції розвитку та напрями діяльності зазнали певних змін, що варті уваги дослідників не лише з наукової, а й з практичної точки зору.

Разом 3 тим, означена наукова проблема є малодослідженою як на загальнодержавному, так і регіональному рівні. Перші наукові розвідки, спрямовані на вивчення особливостей розвитку та діяльності кооперативних товариств, належать до досліджуваного часу, і були підготовлені О. Меркуловим, А. Мініним $[2 ; 6]$. У сучасній українській історіографії проблематика кооперативного руху набула широкого вивчення. Проте висвітлення особливостей розвитку кооперації у воєнний період розглядалося в контексті загальних робіт з історії кооперативного руху в Україні В. Марочка, А. Фаренія [5; 17]. Окрему увагу дослідженню означеної проблеми присвятили О. Реєнт, О. Сердюк, які вважали, що діяльність кооперативних товариств сприяла пом'якшенню економічної кризи в умовах Першої світової війни [9]. Разом з тим дослідники не ставили собі за завдання аналіз регіональних особливостей розвитку кооперативного руху. 3 огляду на це метою статті $\epsilon$ вивчення особливостей розвитку кооперативного руху на Півдні України в умовах Першої світової війни.

У дослідженні було використано комплекс історичних джерел. Серед них неопубліковані матеріали Державного архіву Автономної Республіки Крим, Інституту рукописів Національної бібліотеки України імені В. І. Вернадського. У роботі було використано статистичні джерела, матеріали періодичної преси, зокрема журналів «Вестник кооперации», «Южный кооператор». Залучення різноманітних за характером джерел дає можливість претендувати на репрезентативність дослідження та об'єктивність його висновків.

3 початком Першої світової війни сформувалися нові, відмінні від попередніх, соціально-економічні умови розвитку кооперативного руху. Вони мали неоднозначний характер і по-різному впливали на розвиток різних видів кооперативних організацій.

Однією з перших проблем воєнного часу, спільною для кооперативів усіх напрямів діяльності, стала мобілізація їхніх членів, працівників. За наявними даними лише у Тираспільському, Ананіївському, Одеському, Ізмаїльському та Аккерманському повітах Херсонської губернії до кінця 1914 р. було мобілізовано більше 14,7 тис. членів кредитних кооперативів [7]. Це було значною втратою для кооперативного руху, оскільки членський склад поповнювався досить повільно, а підготовка нового працівника потребувала певного часу.

3-поміж всіх видів кооперативів найкраще адаптуватися до воєнних умов вдалося споживчій кооперації. Характерні для досліджуваного часу інфляція, 
підвищення цін, продовольчий дефіцит стали певними стимулами до розвитку цього напряму кооперативного руху.

Діяльність споживчих товариств була спрямована на забезпечення населення якісними та прийнятними за цінами товарами. Ці завдання набували у воєнний час особливої актуальності. У регіоні, як і в цілому по країні, спостерігався ріст цін. Так, у 1915 р. в Одесі ціни, порівняно з 1911 р., збільшилися на пшеницю - на $19 \%$, муку - $20 \%$, масло соняшникове - $32 \%$, $[5,11]$. Серед населення ширилися панічні настрої, пов'язані із закупівлею продукції та товарів. Формувалися групи дефіцитних товарів, а саме: цукор, керосин, дрова, вугілля. Спостерігалася масова спекуляція.

Зазначені фактори сприяли створенню населенням споживчих товариств. На 1 січня 1917 р. на Півдні України діяло близько 1 тис. споживчих кооперативів, що було майже вдвічі більше, порівняно з показниками на 1 січня 1914 р. [15]. Це дало привід російському досліднику О. В. Меркулову називати Першу світову війну «межею, що відкрила новий період особливо швидкого росту споживчої кооперації» $[2,14]$.

Діяльність споживчих товариств певною мірою сприяла пом'якшенню економічної кризи. Проте, в умовах інфляції, загального підвищення цін, через товарний дефіцит, проблематичність у пошуку постачальників товарів споживчим товариствам було складно утримувати ціни на рівні ринкових і нижче за них. Московським союзом споживчих товариств було порівняно ціни у споживчих товариствах та у приватних торгівельних закладах Південно-Західної частини Російської імперії станом на 1 червня 1915 р. На деякі товари (борошно, пшеницю, ячмінь, гречку та яловичину) кооперативні ціни навіть були вищими, ніж у приватних крамницях. Разом з тим дефіцитний на той час цукор, а також сіль, керосин у кооперативах коштували дешевше [16, 6-17].

Окремі споживчі товариства створювалися з метою особистого збагачення їхніх засновників, і не відповідали завданням кооперативної самодопомоги. Вони засновувалися лише для того, щоб мати змогу придбати товар, а потім перепродати його за спекулятивними цінами.

Менш інтенсивно у кількісному відношенні в умовах війни розвивалася кредитна кооперація. Причиною цього в першу чергу було скорочення державного фінансування. Представники кредитних кооперативів Таврійської губернії на запит інспектора дрібного кредиту про вплив війни на стан їхніх справ також зазначали, що через мобілізацію, призупинення темпів розвитку господарства зменшилася потреба населення у кооперативному кредитуванні. Члени товариств у зв'язку з фінансовими труднощами, низьким врожаєм не могли вчасно повернути борги по кооперативним позикам. Разом з тим вкладники поспішали 
забрати свої заощадження, що погіршувало і без того складне фінансове становище товариств [8, 7-19]. Ці фактори стали результатом того, що, порівняно 3 1914 р., кількість кредитних товариств у 1916 р. зросла лише на 5 \% [10, 558-567].

Через зменшення державного фінансування скоротилися також темпи розвитку сільськогосподарської кооперації. За неповними даними у досліджуваному регіоні кількість сільськогосподарських кооперативів на 1 січня 1917 р., порівняно з початком 1914 р., суттєво не змінилася і приблизно складала 280 організацій (250 - громад і 30 - товариств) [9, 27-29].

У роки війни сільськогосподарські, а особливо кредитні кооперативи, активізували посередницький напрям роботи, який полягав у придбанні в селян сільськогосподарської продукції з подальшим перепродажем державі. Як правило, ці товари призначалися на військові потреби. Розвитку цього напряму діяльності сприяло і географічне розташування регіону, наявність виходу до Азовського, Чорного морів, розміщення портів. Так, у 1905 р. лише 6 із 43, тобто $13 \%$, ощадно-позичкових кооперативів, підзвітних Таврійському губернському комітету у справах дрібного кредиту, займалися посередницькими операціями. У 1914 р. таких товариств вже нараховувалося 61, і вони складали 65 \% від загальної кількості кооперативів, що підпорядковувалися цьому комітету [13].

Одним із центрів кооперативного збуту зерна було Акимівське кредитне товариство Мелітопольського повіту. Кооператив знаходився неподалік від доріг, що вели до торгових портів Феодосії та Генічеська. Він мав три власні склади для зберігання зерна, а також спеціальних агентів на біржах і ринках, які слідкували за цінами на хліб. Лише з 10 квітня до 25 липня 1915 р. кооперативом на потреби армії було поставлено 2,4 тис. т ячменю, 1,95 тис. т пшениці, 399 т жита і 14 т вівса [12, 1, 5-8].

Під час війни на Півдні України продовжував розвиватися артільний рух. У регіоні діяли промислові, сільськогосподарські та обслуговуючі артілі. До першої групи належали об'єднання робітників з обробки металу, каменю, виготовлення взуття та одягу, до другої - молочні артілі. Обслуговуючі мали різноманітний спектр діяльності, зокрема це були артілі посильних, офіціантів, перукарів, вантажників $[4,13]$.

В умовах війни більш активно розвивалася справа створення кооперативних спілок. Держава підтримувала їхнє утворення, оскільки вбачала в них дієві заклади із закупівлі та постачання армії необхідними сільськогосподарськими продуктами. Протягом 1915-1916 рр. в Південній Україні було відкрито 32 спілки кооперативів. Найбільше їх було відкрито в Катеринославській губернії - 16, дещо менше у Херсонській - 12 і лише 4 у Таврійській. За характером у регіоні переважали спілки кредитних та споживчих кооперативів, їх було по 13. Значно 
менше на Півдні України працювало мішаних спілок, які об'єднували кооперативи різного напряму діяльності, а саме: 6 установ [14, 3-5, 13-14, 19-21].

Особливої ваги у роки Першої світової війни набула благодійна справа кооперативів, що стала спільною тенденцією для всіх напрямів товариств. 3 перших днів війни Петроградський комітет сільських, ощадно-позичкових і промислових товариств звернувся зі сторінок «Вестника кооперации» до кооперативів із закликом не припиняти їхню діяльність, а, навпаки, розвивати іiі, пристосовуючи до нових умов. Комітет закликав кооперативи допомагати родинам мобілізованих, створювати спілки і розширювати культурно-просвітницьку роботу $[1,1-3]$.

Кооперативна благодійність щодо військових під час Першої світової війни проявлялася у різних формах. Найпоширенішою було відшкодування коштів на потреби армії, на будівництво лікарень, різним комітетам опіки військовими і пораненими, Червоному хресту. Так, кооперативне товариство в с. Стила Маріупольського повіту у 1915 р. пожертвувало 200 крб на допомогу пораненим та 50 крб місцевому закладу опіки за ними [17, 21-22]. Янченранське товариство Таврійської губернії відраховувало кошти на будівництво польового лазарету від Мелітопольського повіту і на користь Червоного хреста $[8,4]$.

Окремі кооперативи регіону самостійно облаштовували для хворих і поранених воїнів невеликі лікарні або окремі ліжка в місцевих лікарнях. Зокрема, Григоріївський кредитний кооператив Таврійської губернії підготував будинок для розміщення 10 легкопоранених воїнів 3 повним їхнім утриманням $[8,11]$.

Кооперативи хвилювала і важлива для армії проблема забезпечення військових одягом. Зокрема, за ініціативи голови ради Ново-Троїцького ощаднопозичкового товариства Таврійської губернії отця Олександра Бодіна була створена майстерня для виготовлення теплого одягу для солдат, у якій працювали на добровільній, безоплатній основі місцева інтелігенція, міщани, селяни $[8,8]$.

Особливу увагу південноукраїнські кооперативи приділяли наданню допомоги мобілізованим членам та їхнім родинам. Щоб не обтяжувати становище родин, які залишилися без годувальників, кредитні кооперативи надавали відстрочки на виплату кооперативних позик. Терміни їх були різними. Так, у АджиІбранському ощадно-позичковому товаристві Таврійської губернії вони складали 6 місяців, а Верхньорогачинський кооператив цієї ж губернії подовжив термін виплати позик мобілізованим членам до закінчення війни, або до їхнього повернення додому $[8,7,21]$.

Кооперативи також надавали матеріальну допомогу таким родинам, а окремі з них, як Ставищинське ощадно-позичкове товариство Херсонщини, Салбинське ощадно-позичкове товариство Таврійської губернії, продовжували випла- 
чувати заробітну плату членам правління, службовцям, працівникам кооперативів, мобілізованим на війну [3].

Товариства не обмежувалися лише матеріальною підтримкою родин мобілізованих членів, а й допомагали їм фізично. Зокрема, Мелітопольська спілка закладів дрібного кредиту організувала для них спільний товариський обмолот хліба і його збирання $[19,26]$.

Отже, у роки Першої світової війни кооперативний рух на Півдні України набув особливих рис розвитку. Спостерігалося стрімке збільшення кількості споживчих товариств, що було зумовлено інфляцією, продовольчим дефіцитом воєнного часу. Менш інтенсивно в кількісному відношенні розвивалася сільськогосподарська та кредитна кооперація, оскільки ці напрями кооперативного руху залежали від державного фінансування. У роки війни збільшилися обсяги посередницьких операцій кооперативних організацій регіону. Вони виконували важливу економічну функцію, оскільки були спрямовані на забезпечення армії сільськогосподарською продукцією і були вигідні як селянам, так і державі. Провідним напрямом діяльності товариств у воєнні роки була благодійна діяльність, спрямована на допомогу військовим, мобілізованим членам товариств та їхнім родинам.

\begin{abstract}
The article is devoted to the peculiarities of the development of the cooperative movement in the south of Ukraine in the conditions of the First World War. The methodological basis of the study is a set of general scientific and historical methods of cognition: methods of logical analysis, synthesis, comparison, classification, problem-chronological, historical-typological, statistical-analytical. The principles of historicism, scientific objectivity and systematicity were adhered to.

A comprehensive analysis of the scientific literature and sources using the methodological approaches identified makes it possible to draw a number of conclusions.

The deployment of the First World War created new socio-economic conditions for the development of the cooperative movement. They were to reduce government funding; mobilization of some members and employees of cooperatives; goods shortages and price increases; problematic search for suppliers; halting the pace of agricultural development and reducing the need for cooperative lending.

As a result of the adaptation of the cooperative movement to military conditions, there was an increase in the number of consumer societies whose activities were aimed at providing the population with quality and affordable goods. The intensity of development of credit and agricultural cooperatives decreased during the war. The societies of these activities have expanded the volume of mediation operations to provide the army with agricultural produce. The cooperative societies paid special attention to charities, assisted the army, the families of the mobilized members.

The importance of the study lies in the actualization of this problem at the regional level; a comprehensive study of the features of the development of the cooperative movement of the South of Ukraine in the conditions of the First World War. The study of this topic is not exhaustive, it requires further study, in particular refinement of statistical indicators, analysis of cultural and educational activities.
\end{abstract}

Keywords: war, cooperative movement, socio-economic relations, society. 


\section{ДЖЕРЕЛА ТА ЛІТЕРАТУРА}

1. Воззвание Петроградского комитета о сельских ссудо-сберегательных и промышленных товариществах. Вестник кооперации. 1914. № 6-7. С. 1-3.

2. Глебов (Меркулов) А. В. Сельскохозяйственные общества. Петроград: Мысль, 1918. $14 \mathrm{c}$.

3. Кооперативная хроника. Южный кооператор. 1914. № 17. С. 458; Держархів АР Крим, ф. 70, оп. 1, спр. 390, арк. 26-27.

4. Краткий статистико-экономический обзор по Одесскому уезду за 1916-1917 гг. Одесса: [б. и.], 1920. С. 13.

5. Марочко В. І. Українська селянська кооперація. Історико-теоритичний аспект (1861-1929 рр.) Київ: Kots Publishing, 1995. 224 с.

6. Минин А. Война, хозяйство и кооперация Москва: Комитет сельских, ссудосберегат. и пром. товариществ, 1915. 54 с.

7. Несколько данных о положении дела в кредитных и ссудо-сберегательных товариществах Одесской конторы государственного банка. Южный коопеpamop. 1914. № 20. С. 533.

8. Об участии товариществ района Симфиропольского отделения государственного банка в дели помощи войнам и их семьям, 1914-1915 гг. Держархів АР Крим. Ф. 70. Оп. 1. Спр. 390. 90 арк.

9. Покуль О. Сільськогосподарська кооперація на Україні: (статистичні відомості) Сільський господар. 1919. Ч. 20-21. С. 28.

10. Реєнт О., Сердюк О. Перша світова віна і Україна. Київ: Генеза, 2004. 482 с.

11. Сборник статистико-экономических сведений по сельскому хозяйству России и иностранных государств / Министерство земледелия Отдел сельской экономии и сельскохозяйственной статистики. Петроград: Екатеринославская типография, 1917. Вып. 10. $670 \mathrm{c.}$

12. Сведения о поставках хлеба в армию, 1914-1915 гг Держархів АР Крим. Ф. 70. Оп. 1. Спр. 389. 39 арк.

13. Сводные отчеты за 1905 г., 1906 г. Таврический губернский комитет по делам мелкого кредита, 1907 г. Держархів АР Крим. Ф. 70. Оп. 1. Спр. 64, арк. 16; Отчеты ссудо-сберегательных товариществ Таврический губернский комитет по делам мелкого кредита за 1914 г. Держархів АР Крим. Ф. 70. Оп. 1. Спр. 386. арк. 43.

14. Список кооперативных союзов Украины на 1.01.1919. Київ: Друкарня союзу споживчих союзів України, 1919. 46 с.

15. Список обществ и союзов-членов тов-ва ПОЮР, 1917-1918 гг. ІР НБУВ. Ф. 290. Спр. 516. 2 арк.; Список потребительных обществ членов товарище- 
ства потребительных обществ Юга России. Южно-русский потребитель. 1915. № 3. C. 20-21.

16. Таблицы средних справочных цен и средних цен потребительских обществ по районам Европейской России на 1 июня 1915 г. По данным анкеты Всероссийского союза городов и МСПО. Москва: Городская типография, 1915. 17 с.

17. Тульський К. Село Стылы Мариупольского уезда Екатеринославской губернии. Южно-русский потребитель. 1915. № 4. С. 21-22.

18. Фареній I. А. Кооперативний рух у Наддніпрянській Україні в другій половині XIX - на початку XX ст.: монографія Черкаси: Відлуння-Плюс, 2008. 432 с.

19. Фрометт Б. Война и культурно-общественные задачи кооперации. Вестник кооперащии. 1914. № 6-7. С. 26.

\section{References}

1. (1914). Vozvanie Petrogradskogo komiteta o selskih ssudo-sberegatelnyh i promyshlennyh tovarishestvah [Cooperative partnerships and societies]. Vestnik kooperacii, 6-7, 1-3.

2. Glebov, (Merkulov) A. V. (1918). Selskohozyajstvennye obshestva [Agricultural companies]. Petrograd: Mysl.

3. (1914). Kooperativnaya hronika [Cooperative Chronicle]. Yuzhnyj kooperator, 17, 458; Ob uchastii tovarishestv rajona Simfiropolskogo otdeleniya gosudarstvennogo banka v deli pomoshi vojnam i ih semyam, 1914-1915. [On the participation of partnerships in the district of the Simfiropol branch of the state bank in helping the wars and their families, 1914-1915] SAARC (State Archives in the Autonomous Republic of Crimea), F. 70. Op. 1. F. 390.

4. (1920). Kratkij statistiko-ekonomicheskij obzor po Odesskomu uezdu za 19161917 [A brief statistical and economic review of the Odessa county for 19161917]. Odessa.

5. Marochko, V. I. (1995). Ukrainska selianska kooperatsiia. Istoryko-teorytychnyi aspekt (1861-1929) [Ukrainian Peasant Cooperation. Historical and theoretical aspect (1861-1929)]. Kyiv: Kots Publishing.

6. Minin, A. (1915). Vojna, hozyajstvo i kooperaciya [War, economy and cooperation]. Moskva: Komitet selskih, ssudo-sberegat. i prom. tovarishestv.

7. (1914). Neskolko dannyh o polozhenii dela v kreditnyh i ssudo-sberegatelnyh tovarishestvah Odesskoj kontory gosudarstvennogo banka [Some data on the situation in credit and loan-savings partnerships of the Odessa branch of the state bank]. Yuzhnyj kooperator, 20.

8. Ob uchastii tovarishestv rajona Simfiropolskogo otdeleniya gosudarstvennogo banka v deli pomoshi vojnam $\mathrm{i}$ ih semyam, 1914-1915. [On the participation of 
partnerships in the district of the Simfiropol branch of the state bank in helping the wars and their families, 1914-1915] SAARC, F. 70. Op. 1. F. 390.

9. Pokul, O. (1919). Silskohospodarska kooperatsiia na Ukraini: (statystychni vidomosti) [Agricultural cooperation in Ukraine: (statistical data)]. Silskyi hospodar, 20-21.

10. Reient, O., Serdiuk, O. (2004). Persha svitova vina i Ukraina [World War I and Ukraine]. Kyiv: Heneza.

11. (1917). Sbornik statistiko-ekonomicheskih svedenij po selskomu hozyajstvu Rossii i inostrannyh gosudarstv [Collection of statistical and economic information on the agriculture of Russia and foreign countries]. Petrograd: Ekaterinoslavskaya tipografiya.

12. Svedeniya o postavkah hleba $\mathrm{v}$ armiyu, 1914-1915 [Information on the supply of grain to the army]. SAARC, F. 70. Op. 1. F. 389.

13. Svodnye otchety za 1905, 1906. Tavricheskij gubernskij komitet po delam melkogo kredita 1915 [Consolidated Reports for 1905, 1906 Tauride Provincial Committee for Small Credit Affairs]. SAARC, F. 70. Op. 1. F. 64; Otchety ssudosberegatelnyh tovarishestv Tavricheskij gubernskij komitet po delam melkogo kredita za 1914 [Reports of savings and loan partnerships Taurida Provincial Committee for Small Credit Affairs for 1914]. SAARC, F. 70. Op. 1. F. 386.

14. (1919). Spisok kooperativnyh soyuzov Ukrainy na 1.01.1919 [List of cooperative unions of Ukraine on 01/01/1919]. Kiyiv: Drukarnya soyuzu spozhivchih soyuziv Ukrayini.

15. Spisok obshestv i soyuzov-chlenov tovarishestva POYuR, 1917-1918 [List of Societies and Unions-Members of the Partnership of the Consumer Society of the South of Russia, 1917-1918]. Institute of Manuscripts of National library of Ukraine (IM NLU). F. 290. F. 516; (1915) Spisok potrebitelnyh obshestv chlenov tovarishestva potrebitelnyh obshestv Yuga Rossii [List of consumer associations of members of the partnership of consumer societies of the South of Russia]. Yuzhno-russkij potrebitel, 3.

16. (1915). Tablicy srednih spravochnyh cen i srednih cen potrebitelskih obshestv po rajonam Evropejskoj Rossii na 1 iyunya 1915 g. Po dannym ankety Vserossijskogo soyuza gorodov i MSPO [Tables of average reference prices and average prices of consumer societies by region of European Russia as of June 1, 1915. According to the questionnaire of the All-Russian Union of Cities and the Moscow Union of Consumer Societies]. Moskva: Gorodskaya tipografiya.

17. Tulskij, K. (1915). Selo Styly Mariupolskogo uezda Ekaterinoslavskoj gubernii. [Village of Styly, Mariupol County, Yekaterinoslav Province]. Yuzhno-russkij potrebitel, 4. 
18. Farenii, I. A. (2008). Kooperatyvnyi rukh u Naddniprianskii Ukraini v druhii polovyni XIX - na pochatku XX st. [The cooperative movement in the Dnieper Ukraine in the second half of the XIX-early XX c.]. Cherkasy: Vidlunnia-Plius, 2008.

19. Fromett, B. (1914). Vojna i kulturno-obshestvennye zadachi kooperacii [War and the cultural and social tasks of cooperation.]. Vestnik kooperacii, 6-7.

УДК 323.1:81’246.3(477.52/.6)

\section{МОВНА СТРУКТУРА НАСЕЛЕННЯ ПІВДЕННОЇ УКРАЇНИ (ЗА МАТЕРІАЛАМИ ВСЕСОЮЗНОГО ПЕРЕПИСУ НАСЕЛЕННЯ 1926 РОКУ)}

\section{Малярчук Наталя}

Автором проаналізовано склад населення Південної України за рідною мовою, розглянуто особливості мовної структури по окремих округах, а також міських та сільських поселеннях регіону, здійснено порівняльний аналіз етнічної та мовної структур населення, визначено рівень та характер асимілячійних процесів в регіоні та по УСРР загалом.

За підсумками дослідження автор дійшов висновків, що у 1926 р. абсолютна більшість населення Південної України вважала своєю рідною мовою українську. Аналіз мовної структури населення окремих округ Південної України показав, щзо у більшості з них, окрім Одеської, переважало україномовне населення. Російська, яку визнали рідною менше чверті населення, була другою за демографічною потужністю мовою регіону. Проте вона мала більшу комунікаційну потужність $i$, як наслідок, більший асиміляційний потенціал, ніж украӥнська. Мови інших народів, щзо проживали на території регіону, загалом посідали незначне місце у його мовному середовищі.

Порівняльний аналіз етнічної та мовної структури населення Південної Украӥни показав, щуо украӥнці, попри свою чисельну перевагу, здійснювали дуже незначний асиміляційний вплив на інші етнічні спільноти регіону. Більще того, вони самі зазнавали асиміляції з боку російської етнічної меншини. Це дозволило зробити висновок про деформованість мовної ситуації у регіоні, а також про неприродний та асиметричний характер асиміляційних проиесів. Російський асиміляційний вплив найбільш потужно проявлявся у великих містах - адміністративних, економічних та культурних иентрах Півдня України. У невеликих містах та сільських поселеннях процес російської асиміляиії відбувався повільніше, і для населення більшості з них рідною була українська мова.

Автором зроблено висновок, щзо хоча в иілому русифікація на Півдні України у 1926 р. ще не набула загрозливого характеру, і для абсолютної більшості населення рідною була мова власної національності, проте асиміляційні процеси в регіоні відбувалися більш інтенсивно, ніж загалом по УСРР.

Ключові слова: росіяни, україниі, Всесоюзний перепис населення 1926 р., Південна Україна, російська мова, украӥнська мова. 